\title{
EFFICIENCY OF COLORIMETRIC TESTS TO DETERMINE POLLEN VIABILITY IN PEPPERS
}

Letícia da Guia Alves de Jesus ${ }^{1}$, Raimundo Nonato Oliveira Silva ${ }^{1}$, Maria Fernanda da Costa Gomes ${ }^{2}$, Sérgio Emílio dos Santos Valente ${ }^{3}$, Regina Lucia Ferreira Gomes ${ }^{4}$, Angela Celis de Almeida Lopes ${ }^{4}$, Marcones Ferreira Costa ${ }^{1 *}$

\begin{abstract}
Estimating pollen viability is important for analyzing genetic flow, evaluating the masculine reproduction potential of a species, and for genetic improvement programs. In order to gather more information about different pepper accessions (Capsicum sp) held in the Active Germplasm Bank of the Federal University of Piauí (BAG-UFPI), Brazil, we analyzed the pollen viability of eight pepper accessions using four colorimetric methods: $2 \%$ acetic carmine; $2 \%$ acetic orcein; fuchsin; and Lugol's iodine. Pre-anthesis floral buds were collected and fixed in ethanol:acetic acid (3:1) for 24 hours and subsequently held in $70 \%$ ethanol under refrigeration until the slides were prepared using the squashing technique. An entirely randomized methodology was used, and the data compared using the Scott-Knott test at a 5\% probability level. The four colorimetric methods were found to be efficient for estimating pollen viability in the different plant accessions, with all of them demonstrating high pollen viability (above 70\%) - an important index for studies of genetic improvement.
\end{abstract}

Keywords: acetic carmine, acetic orcein, Capsicum, genetic crossing.

\section{EFICIÊNCIA DE TESTES COLORIMÉTRICOS PARA DETERMINAR A VIABILIDADE POLÍNICA EM PIMENTAS}

\begin{abstract}
RESUMO - A estimativa de viabilidade polínica é importante para a análise de fluxo gênico e evidencia o potencial de reprodução masculina da espécie, sendo útil para os programas de melhoramento genético. Com o intuito de fornecer informações a respeito dos acessos de pimentas (Capsicum sp) provenientes do Banco Ativo de Germoplasma da Universidade Federal do Piauí (BAG-UFPI), objetivou-se estimar a viabilidade polínica de oito acessos, através de quatro métodos coloriméticos: carmim acético $2 \%$, orceína acética $2 \%$, fucsina e lugol. Foram coletados os botões florais na pré-antese e fixados em etanol:ácido acético (3:1) por 24 horas e, posteriormente, permaneceram em etanol 70\% sob refrigeração até a preparação das lâminas pela técnica de esmagamento. Foi utilizado um delineamento inteiramente casualizado em esquema fatorial e os dados foram comparados pelo teste Scott-Knott ao nível de 5\% de probabilidade de erro. Os quatro métodos colorimétricos foram eficientes em estimar a viabilidade entre os acessos, os quais apresentaram alta viabilidade polínica com valores acima de 70\%, importante para viabilização dos trabalhos de melhoramento genético em pimentas.
\end{abstract}

Palavras chave: carmim acético, Capsicum, cruzamentos genéticos, orceína acética.

\footnotetext{
${ }^{1}$ Universidade Federal do Piauí, Campus Amílcar Ferreira Sobral, BR 343, km 3,5 - Bairro Meladão, Floriano, PI, Brasil, 64808-605.*Autor para correspondência: marconescosta@ufpi.edu.br

${ }^{2}$ Universidade Federal do Piauí, Programa de Pós-Graduação em Genética e Melhoramento, Campus Socopo, Teresina, PI, Brasil, 64049-550.

${ }^{3}$ Universidade Federal do Piauí, Centro de Ciências da Natureza, Departamento de Biologia, Campus Ininga, Teresina, PI, Brasil, 64049-550.

${ }^{4}$ Universidade Federal do Piauí, Departamento de Fitotecnia, Centro de Ciências Agrárias, Teresina, PI, Brasil, 64049-550.
} 


\section{INTRODUCTION}

Peppers of the genus Capsicum sp, much like eggplants, tomatoes, and tobacco, belong to the botanical family Solanaceae, whose fruits have been used as foods and spices for more than 6000 years; they contain distinct chemical compounds that have medicinal and pharmacological applications (Meckelmann et al., 2013).

The genus Capsicum comprises more than 30 species, five of which are extensively cultivated: Capsicum annuum, Capsicum frutescens, Capsicum chinense, Capsicum baccatum, and Capsicum pubescens (Bosland et al., 2012). Peppers have strong aromas and pungent flavor characteristics - which make them important ingredients in the daily diets of millions of people around the world.

The genus is classified according to its floral and fruit morphologies, and by its chromosome number $(2 n=24$ or 26$)$. Cultivated and semi-domesticated species, as well as some wild species, show predominant chromosome numbers of $2 n=24$, while the more primitive species have karyotypes with $2 \mathrm{n}=26$ (Wahyuni, 2013); all of them produce a wide variety of chemical substances with therapeutic properties.

The extracts of C. annum and C. frutescens demonstrate proven antibacterial activities, and have been shown to be efficient as natural bactericidal agents against Vibrio cholerae, Staphylococcus a-ureus, and Salmonella typhimurium (Koffi-Nevry et al., 2012). Although the fruits of pepper plants are principally consumed because of their flavors, aromas, and colors, some Amerindian tribes use them in their traditional medicinal pharmacopeia to treat asthma, coughing, sore throats, and toothaches (Singletary, 2011).

According to Wahyuni et al. (2013), pepper fruits are sources of capsinoids, carotenoids (provitamin A), flavonoids, ascorbic acid (Vitamin C), and tocopherols (Vitamin E); they are also considered important sources of antioxidants due to the presence of polyphenolic compounds (such as derivatives of cinnamic acid and flavonoids) that can eliminate free radicals.

Due to these properties, there has been considerable discussion about using peppers to treat cancer, anemia, diabetes, and cardiovascular diseases (Bosland et al., 2012). As such, the biochemical compositions of Capsicum species are not only important to the plants themselves, but may offer remedies for human health (Zimmer et al., 2012).

There is considerable genetic variability among the different species of the genus Capsicum in terms of their morphological, cytogenetic, and biochemical characteristics that will be important to programs of genetic improvement designed to develop superior cultivars containing genes for disease resistance, greater adaptability to adverse climatic conditions, and the production of high concentrations of chemical components useful to the pharmaceutical industry.

Pollen viability ranks high among the critical factors influencing successful plant improvement programs through hybridization, favoring the formation of viable and balanced gametes (Martins et al., 2010) - which will directly influence fertilization success, as there is a linear relationship between pollen viability, germination capacity, and fruit formation (Sulusoglu \& Cavusoglu, 2014).

Pollen viability can be evaluated by number of different techniques, which can be classified as direct (with visual observations of in vitro or in vivo pollen germination, confirmation of pollen tube growth within the stigma, and seed formation) or indirect (based on colorimetric or histochemical tests) (Dafni et al., 2005; Abdelgadir et al., 2011). Another test of pollen viability involves manual pollination and the subsequent observation of fruit setting; however, due to the longer time frames involved in those evaluations, other methods are more frequently utilized (Karayaya, 2011).

There are a number of histochemical staining methodologies that can be used to estimate pollen viability, including the use of acetic orcein, acetic carmine, Alexander staining, lugol's iodine, basic fuchsin, 2,3,5triphenyl tetrazolium chloride (TTC), and Sudan IV (Alexander, 1980; Munhoz et al., 2008). Those stains react with the cellular components of mature pollen grains, resulting in color changes that allow distinctions between viable and unviable grains.

Colorimetric tests are more rapid, less expensive, and more practical than other techniques but generally overestimate pollen viability, making it important to test various staining techniques to determine which come closest to true viability values.

As such, we estimated the pollen viability of eight Capsicum accessions from the Active Germplasm Bank 
of the Federal University of Piauí (BAG-UFPI), using four different colorimetric methods to identify fertile genotypes with potential utility for genetic improvement programs through hybridization.

\section{MATERIALS AND METHODS}

The botanical material tested consisted of eight accessions of Capsicum held in the Active Germplasm Bank of the Federal University of Piauí (BAG-UFPI), Brazil: G-06, G-07, G-12, G-23, G-28, G-30, G-31, and G-34. Their seeds were germinated in $500 \mathrm{~mL}$ plastic cups and subsequently transferred to planting pots and maintained under environmental conditions recommended for their cultivation.

During the flowering periods of the pepper accessions, pre-anthesis floral buds were collected and fixed in an ethanol: acetic acid (3:1) solution for $24 \mathrm{~h}$ and subsequently transferred to $70 \%$ alcohol and held under refrigeration until used.

The slides were prepared using the anther squashing technique, as described by Guerra \& Souza (2002). Four distinct staining compounds were used $(2 \%$ acetic orcein, $2 \%$ acetic carmine, lugol, and fuchsin) allowing us to not only estimate pollen viability, but also to determine which stains were more efficient with Capsicum species. A drop of each stain was applied to slides containing the pollen grains, which were subsequently examined under a light microscope (40X objective).

The methodology employed was completely randomized in an eight $\mathrm{x}$ four factorial scheme (plant accessions $\mathrm{x}$ stains), using three slides with each stain; 500 pollen grains were observed per slide, totaling 1500 grains per test, and 6000 grains for each plant variety (considering the four stains used). The data was submitted to analysis of variance (ANOVA) and the values compared by the Scott-Knott test, at a 5\% level of probability, using Assistat ${ }^{\circledR}$ beta version 7.7 software.

\section{RESULTS AND DISCUSSION}

The results of the colorimetric evaluations of the pollen grains of the eight different pepper accessions examine are presented in Table 1. There were significant variations in the percentages of viable pollen grains among the different accessions, reflecting genetic variability between them; it was also possible to observe significant differences between the results of the four different stains tested. The coefficient of variation of the experiment was $6.20 \%$, indicating high experimental precision.

The different plant accessions all demonstrated high pollen viability as measured by all of the stains used. According to Souza (2002), pollen viability indices above $70 \%$ are considered high; between 31 and $69 \%$ are considered medium, while indices below $30 \%$ are considered low. Low pollen viability can indicate reproductive problems in plants, including infertility, and possible meiotic problems resulting in different degrees of sterility (Hister \& Tedesco, 2016).

Other researchers have likewise reported high pollen viability values in species of the genus Capsicum $s p$ [e.g., Côrrea et al. (2007); Pozzobon et al. (2011); Martins et al. (2010); and Souza et al. (2012)].

In relation to the efficiencies of the different stains in estimating pollen viability, it can be seen (Table 1) that all of the colorimetric tests demonstrated significant differences in terms of pollen viability values for the different plant accessions. The pollen staining patterns of the different reagents are shown in Figure 1.

Pollen grain viability tends to diminish over time in response to various environmental factors (Figueredo, 2013). Pepper variety G-06 demonstrated viability above $90 \%$ with all of the stains tested, with no significant differences being observed between the different staining compounds used - indicating the high potential for using that pepper variety in improvement programs using hybridization. The variety G-30 demonstrated the lowest mean viability values with all of the stains tested, although that genotype could still be successfully used in genetic crosses, as its lowest viability value was still above $70 \%$ (Table 1 ).

Corrêa et al. (2007) analyzed the pollen viability of 12 accessions of Capsicum sp from the Embrapa Active Germplasm Bank of Temperate Climate Plants using acetic carmine staining, and obtained a mean value of $96.7 \%$ for $C$. chinense and $63.2 \%$ for $C$. frutescens. Pozzobon et al. (2011) estimated the pollen viability of 12 pepper accessions using acetic orcein, and observed mean pollen viability values above $90 \%$.

The viabilities of the pollen from pepper accessions examined were always greater than $70 \%$ when evaluated using $2 \%$ acetic carmine. This technique is based on 
Table 1 - Mean values of pollen viability of the pepper accessions from the BAG-UFPI for the four staining methods used

\begin{tabular}{ccccc}
\hline Accessions & 2\% Acetic carmine & 2\% Acetic orcein & Fuchsin & Lugol \\
\hline G-06 & $92.83 \% \mathrm{aA}$ & $94.46 \% \mathrm{aA}$ & $94.93 \% \mathrm{aA}$ & $93.60 \% \mathrm{aA}$ \\
G-07 & $81.86 \% \mathrm{bB}$ & $74.96 \% \mathrm{bB}$ & $86.29 \% \mathrm{aB}$ & $98.00 \% \mathrm{aA}$ \\
G-12 & $91.33 \% \mathrm{aA}$ & $93.36 \% \mathrm{aA}$ & $90.53 \% \mathrm{aA}$ & $88.60 \% \mathrm{aA}$ \\
G-23 & $80.03 \% \mathrm{bB}$ & $76.29 \% \mathrm{bB}$ & $75.90 \% \mathrm{bB}$ & $95.40 \% \mathrm{aA}$ \\
G-28 & $85.10 \% \mathrm{aA}$ & $80.20 \% \mathrm{bA}$ & $71.87 \% \mathrm{bB}$ & $82.70 \% \mathrm{bA}$ \\
G-30 & $71.83 \% \mathrm{bB}$ & $72.83 \% \mathrm{bB}$ & $71.80 \% \mathrm{bB}$ & $72.23 \% \mathrm{bB}$ \\
G-31 & $89.40 \% \mathrm{aA}$ & $88.0 \% \mathrm{aA}$ & $76.13 \% \mathrm{bB}$ & $77.40 \% \mathrm{bB}$ \\
G-34 & $73.73 \% \mathrm{bB}$ & $77.40 \% \mathrm{bB}$ & $73.73 \% \mathrm{bB}$ & $79.56 \% \mathrm{bB}$ \\
\hline
\end{tabular}

Uppercase letters on the different accessions indicate significant differences between the stains for each plant variety. Lowercase letters in the different columns indicate significant differences between the stains for each of the plant accessions. *Means followed by the same uppercase letter in each line and by the same lower class letter in each column do not statistically differ by the Scott-Knott test at a $5 \%$ level of probability.

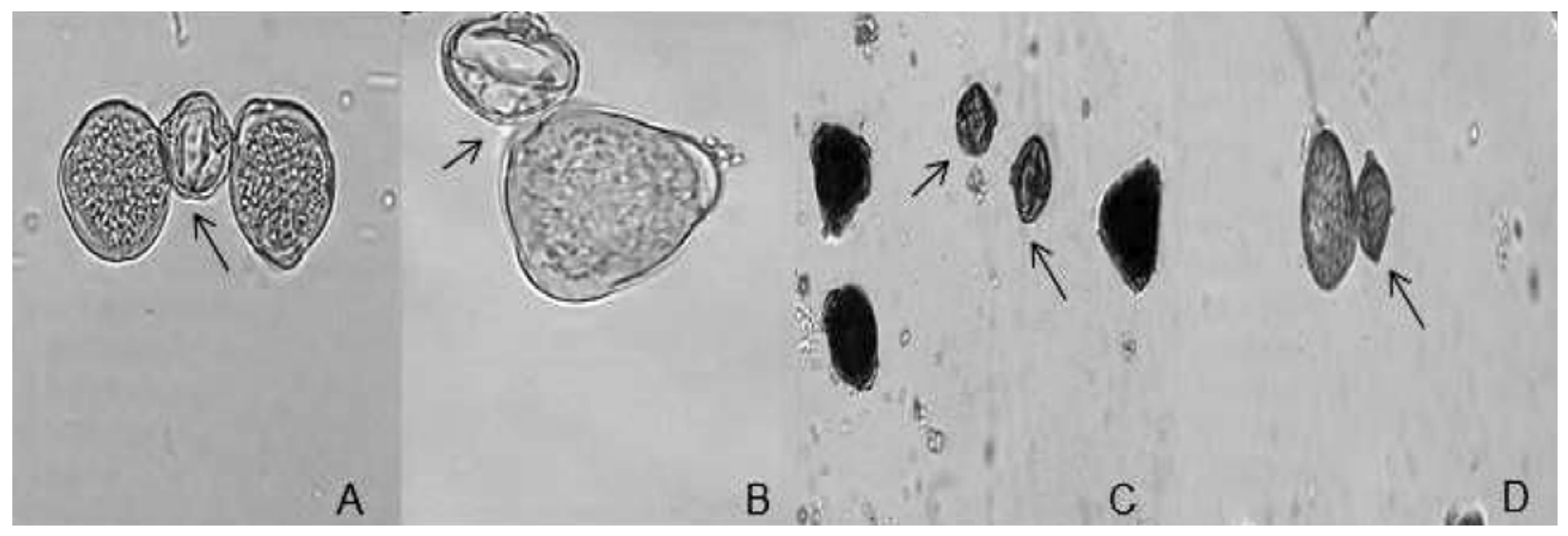

Figure 1 - Pollen grains subjected to different staining methods. A: 2\% acetic carmine; B: 2\% acetic orcein; C: lugol; D: basic fuchsin. Arrows indicate unviable pollen grains

the reaction of that stain with starchy pollen grains, and indicates mature pollen with live protoplasm. Viable pollen grains with intact membranes acquire a red coloration in the presence of $2 \%$ acetic carmine, while unviable pollen grains do not (Figure $1 \mathrm{~A}$ ). When using acetic orcein, strongly colored pollen grains were considered viable, while poorly colored grains were considered unviable (Figure 1B).

Viable pollen grains stained with fuchsin acquire a purplish color, while unviable grains do not, and/ or they demonstrate anomalous morphologies (Figure 1D). Fuchsin is one of the components of the Alexander solution, which has been observed to be quite efficient for evaluating the viability of pepper pollen grains (Souza et al., 2010; Martins et al., 2010). Fuchsin acts by staining the protoplasm of viable pollen grains a pinkish color, while aborted grains do not acquire any coloring due to the absence of a nucleus.

Lugol stains viable pollen grains dark brown, while unviable grains become only light yellow or remain transparent (Figure 1C). The pepper accessions demonstrated high viability levels $(98 \%)$ when stained with lugol, possibly overestimating their viability, as that reagents interacts directly with starch within the pollen grains; species that store only small amounts of starch in their pollen do not react well in tests with lugol.

Moderate environmental temperature changes can reduce pollen grain numbers as well as their viability, generating fertility problems; in severe cases, complete losses of pollen fertility can occur or anther 
dehiscence may be inhibited - with complete fruiting losses (Hedhly, 2011).

In general, colorimetric tests show numerous advantages for pollen viability studies, as they are rapid, inexpensive, and secure, and can aid in the analysis of environmental factors affecting pollen development, the identification of male infertility, the reestablishment of genetic accessions, and determinations of optimal periods for pollination in a given species.

The four histochemical solutions evaluated here were capable of distinguishing viable from unviable pollen grains and were efficient at estimating pollen grain viability percentages. Of the eight pepper accessions from the BAG-UFPI collection that were tested, all showed high pollen viability (greater than $70 \%$ ) - a factor of extreme importance for characterizing those genetic resources and facilitating programs of genetic improvement - and all eight accessions are recommended for use in genetic crosses.

\section{LITERATURE CITED}

\section{ABDELGADIR, H.A.; JOHNSON, S.D.; VAN}

STADEN, J. Pollen viability, pollen germination and pollen tube growth in the biofuel seed crop Jatropha curcas (Euphorbiaceae). South African Journal of Botany, v.79, n.2, p. 132-139, 2011.

ALEXANDER, M.P.A. Versatile stain for pollen fungi, yeast and bacterium. Stain Tecnology, v.1, n.5, p.13-8, 1980.

Bosland, P.W.; VotaVA, E.J. Peppers. Vegetable and Spice Capsicums. 2.ed. CABI: Cambridge, UK, 2012. 204p.

CORRÊA, L.B.; BARBIERI, R.L.; SILVA, J.B. Caracterização da viabilidade polínica em acessos de Capsicum (Solanaceae). Revista Brasileira de Biociências, v.5, n.1, p.660-662, 2007.

DAFNI, A.; KEVAN, P.G.; HUSBAND, B.C. Practical Pollination Biology. Cambridge (Canada): Enviroquest, 2005.315p.

FIGUEIREDO, M.A. Descrição floral, polínica e carpométrica de cultivares de amoreira-preta. 2013. 68 p. Dissertação (Mestrado em Fitotecnia) - Programa de PósGraduação em Agronomia. Universidade Federal de Lavras, Lavras: UFLA, 2013.
GUERRA, M.; SOUZA, M.J. Como observar cromossomos: um guia de técnicas em citogenética vegetal, animal e humana. Ribeirão Preto, SP: FUNPEC, 2002. 131p.

HEDHLY, A. Sensitivity of flowering plant gametophytes to temperature fluctuations. Environmental and Experimental Botany, England, v.74, p.9-16, 2011.

HISTER, C.A.L.; TEDESCO, S.B. "Estimativa da viabilidade polínica de araçazeiro (Psidium cattleianum Sabine) através de distintos métodos de coloração." Revista Brasileira de Plantas Medicinais, v.18, n.1, p.135-141, 2016.

KARAKAYA, D. Effects of inflorescence on pollen viability and morphology of strawberry (Fragaria vesca L.). Journal of Science and Technology, v.1, p.43-47. 2011.

KOFFI-NEVRY, R. et al. Antibacterial activity of two bell pepper extracts: Capsicum annuum L. and Capsicum frutescens. International Journal of Food Properties, v.15, n.5, p.961-971, 2012.

MARTINS, K.C. et al. Meiose e viabilidade polínica em acessos de Capsicum annuum e Capsicum baccatum. Ciência Rural, v.40, n.8, p.1746-1751, 2010.

MECKELMANN, S.W. et al. Compositional characterization of native Peruvian chili peppers (Capsicum spp.). Journal of agricultural and food chemistry, v.61, n.10, p.2530-2537, 2013.

MUNHOZ, M. et al. Viabilidade polínica de Caryca papaya L.: Uma comparação metodológica. Revista Brasileira de Botânica, v.31, n.2, p.209-214, 2008.

POZZOBON, M.T. et al. Meiose e viabilidade polínica em linhagens avançadas de pimenta.

Horticultura brasileira, v.29, n.2, p.212-216, 2011.

SINGLETARY, K. Red Pepper: Overview of Potential Health Benefits. Nutrition Today, v.46, p.33-47, 2011. 
SULUSOGLU, M.; CAVUSOGLU, A. In vitro pollen viability and pollen germination in cherry laurel (Prunus laurocerasus L.). The Scientific World Journal, 2014.

SOUZA M.M.; PEREIRA, T.N.S.; MARTINS, E.R. Microsporogênese e microgametogênese associadas ao tamanho do botão floral e da antera e viabilidade polínica em maracujazeiro-amarelo (Passiflora edulis Sims f. Flavicarpa degener). Ciência Agrotêcnica, Lavras, v.26, n.6, p.1209-1217, 2002.
SOUZA, M.M. et al. Meiotic irregularities in Capsicum L. species. Crop Breeding and Applied Biotechnology, v.12, n.2, p.138-144, 2012.

WAHYUNI, Y. et al. Secondary metabolites of Capsicum species and their importance in the human diet. Journal of natural products, v.76, n.4, p.783-793, 2013.

ZIMMER, A.R. et al. Antioxidant and antiinflammatory properties of Capsicum baccatum: from traditional use to scientific approach. Journal of Ethnopharmacology, v.139, n.1, p.228-233, 2012.

Recebido para publicação em 14/3/2018 e aprovado em 23/6/2018. 